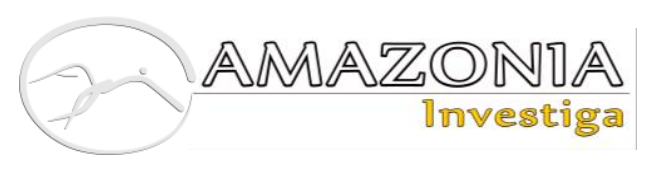

DOI: https://doi.org/10.34069/AI/2021.44.08.25 How to Cite:

Shapoval, R.V., Orlovskyi, R., Sykal, M., \& Zlyvko, S. (2021). Counteraction to offenses committed with the use of electronic payment systems: new challenges and problems. Amazonia Investiga, 10(44), 261-269. https://doi.org/10.34069/AI/2021.44.08.25

\title{
Counteraction to offenses committed with the use of electronic payment systems: new challenges and problems
}

\section{Протидія правопорушенням, учинених із застосуванням електронних платіжних систем: нові виклики та проблеми}

Received: July 30, 2021

Accepted: September 10, 2021

\begin{abstract}
Legal, organizational and technical issues of the current state of crime prevention in the field of electronic payment systems in different countries and in Ukraine are considered. The following methods were used in the article: dialectical, documentary analysis, analytical analysis of documents and observations. Identified and analyzed current trends and risks associated with the use of electronic payment systems by legal entities. Electronic payments have been found to be a progressive and convenient innovation on the one hand, which has greatly accelerated the ability of individuals to engage in day-to-day market relations, and on the other, to be unlawfully encroached upon and systematically improved by criminals. Based on this, emphasis is placed on the urgent need for proper protection of payment systems. It is noted that examples of global counteraction to crimes and various offenses committed in the field of electronic payments are developed countries such as the United States, Great Britain, Canada, Singapore, as well as the European Union, especially France and Germany. As a result of the study, it has been noted that the above countries have all the opportunities to provide Ukraine and its citizens, as well as government officials with the
\end{abstract}

\author{
Анотація
}

Метою статті $є$ розгляд правових, організаційних і технічних питань сучасного стану протидії правопорушенням у сфері використання електронних платіжних систем у різних країнах світу та в Україні. У статті були використані наступні методи: діалектичний, документального аналізу, аналітичний, аналіз документів та спостережень. Виявлені та проаналізовані сучасні тенденції та ризики, пов'язані iз застосуванням суб'єктами правовідносин електронних платіжних систем. Електронні платежі, 3 одного боку, $\epsilon$ прогресивною та зручною новацією, яка у значній мірі прискорила можливість осіб здійснювати повсякденну участь у ринкових взаємовідносинах, 3 іншого - $є$ об'єктом протиправних посягань, які видозмінюються та систематично удосконалюються злочинцями. Відтак, на сьогодні є гостра необхідність у належному захисті платіжних систем. Взірцями світової протидії злочинам i різноманітним правопорушенням, вчинюваним у сфері здійснення електронних платежів, $є$ такі розвинуті країни як Сполучені Штати Америки, Велика Британія, Канада, Сінгапур, а також країни Свропейського Союзу, перш за все Франція та Німеччина. В результаті

\footnotetext{
${ }^{102}$ Doctor of Law (2JD), Professor, Professor at the Department of Administrative Law and Administrative Activities of Yaroslav Mudryi National Law University, Ukraine.

${ }^{103}$ Doctor of Jurisprudence, Associate professor, Professor at the Department of Criminal Law № 1 Yaroslav Mudryi National Law University, Ukraine.

${ }^{104} \mathrm{PhD}$ in Law, Associate Professor, Academy of the State Penitentiary Service, Ukraine.

${ }^{105}$ Doctor of Sciences (Law), Professor, Academy of the State Penitentiary Service, Ukraine.
} 
necessary guidelines, technical and legal assistance to create an effective mechanism to combat offenses in the use of electronic payment systems.

Keywords: electronic payment system, cybercrime, crime prevention, electronic payment.

\section{Introduction}

Perceiving cybersecurity as one of the priority areas of national security is common among both developed and transitional states in today's globalized and digitized world. This is particularly relevant for the relatively young Independent state of Ukraine, which has during the last years repetitively fallen victim to many instances of high-profile malicious activity in cyberspace, the so-called "cyberattacks" (Streltsov, 2017).

Extremely dynamic changes currently continue to undergo in Ukraine like in most foreign countries in the field of payment settlements between the subjects of such public legal relations. The relevant state of affairs in this area is at the same pace with the development of dissemination and exchange of information on the Internet and high information technologies in all countries. Current tendencies indicate that the peculiarity of the development and variability of electronic payment systems is the fact that they, unlike many other areas of society's life, tend to quickly reorient to the latest solutions coming from the leading countries in this area. On the one hand, it gives payment systems more chances to create sufficient security for their own structures and property, especially in the developed world. On the other hand, this situation allows fraudsters, cybercriminals, hackers to attack those subjects of payment relationships who have not had time to adapt in time to the new standards of activity in this area for objective reasons yet.

Modern period of banking technologies development is characterized with modifications of crime, complication of logical connections, new and renovated old ways of abuse, the distinctive difference of which lies in more complex algorithms of perpetrators' actions. According to Klochko (2020, p. 5-7) among the determinants that stipulate the commission of crime in the field of banking in Ukraine, there are: дослідження було відзначено, що саме зазначені вище країни мають усі можливості для надання Україні та іiї громадянам, а також представникам державної влади необхідних методичних рекомендацій, технічної та правової допомоги щодо створення дієвого механізму протидії правопорушенням у сфері використання електронних платіжних систем.

Ключові слова: електронна платіжна система, кіберзлочинність, протидія правопорушенням, електронний платіж.

1) gaps in activities of units and individual law enforcement officers related to immediate counteraction to crime in the field of banking (poor and unprofessional support of objects, untimely and ineffective response to information about crime in the field of banking, etc.);

2) lack of a well-established mechanism of interaction between law enforcement agencies with control bodies and banking institutions;

3) growing number of online banking transactions; new types of online channels, such as online casinos and virtual auctions, the emergence of virtual money;

4) imperfection of regulations governing the operation of banking institutions, as well as the activities of law enforcement and control agencies related to inspections, documentation of criminal activities and criminal proceedings on the grounds of acts that encroach on public relations in the field of banking in Ukraine;

5) political determinants related to gaps in operation of the political subsystem of society, which encompasses a range of tools and forms of interaction of political institutions at different levels, etc.

Thus, these factors clearly indicate the need to strengthen the fight against offenses that are aimed at capturing personal payment data of the subjects of public legal relations or their monetary assets, property, etc.

\section{Literature Review}

It can be argued that the topic of this article is extremely relevant due to the urgency of the problems associated with the functioning of payment systems around the world, as well as the level of their security and protection. From the recent business world and transaction aspect of business relationship becomes more effective 


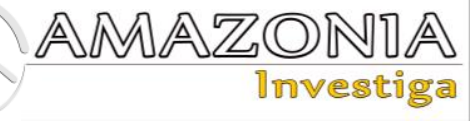

when dealing with the internet and electronic means. Ensuring it's effective implementation it's of utmost importance and desirability as parties becomes satisfactory and confident in such transaction. It there becomes frustrating when such transaction is affected by the so called cybercrimes frustrating the rationale of the electronic transaction. The question one need in posing here is in determine who becomes liable of such forms of crime committed, and what is the situation and position of the law in punishing those who commits such crimes. Moreover, it is not coincident that today in the scientific and specialized literature more and more attention is paid to conducting scientific and expert research on the issues of combating offenses in the field of electronic payment systems.

Trubin (2013) in his monograph "Legal Principles of electronic money functioning of in the field of electronic commerce" has studied the origin and functioning of electronic money, the essence and features of electronic commerce. Based on the study of a new form of payment instrument, the authors have studied electronic money as the main element of the electronic payment system, as the current state and legal regulation of relations in this area. Based on scientific knowledge about the institutions of the information society, the features of information security have been studied and the main directions of improving the legal regulation of public relations related to the functioning of electronic money in Ukraine have been formulated. The problem here is not only the concept or establishing that there is electronic money which parties considers it as effective. The question is asking in knowing what becomes in situation where one of the party violates this contractually obligation and exercising the necessary punishment. We have to bear in mind that, the aspect of electronic payment has suffered lots of handicap and challenges when dealing with it's implementation and enforcement. Most of the transaction are affected by internet crimes.

Herasymov (2018, p. 60-61) has made an attempt to improve the notion of crimes in the sphere of banking activity, has determined them as "the socially dangerous guilty acts under the Criminal Code of Ukraine, encroaching on funds or other property, commercial or banking secrecy of banks and/or their clients, on the procedure of credit and financial transactions in banking institutions, or illegal actions with transfer documents, payment cards and other means of access to bank accounts, electronic money, equipment for their manufacture, committed with the use of banking operations".

Klochko (2019) comprehensively investigated theoretical problems and practical grounds of counteracting crime in the field of banking in Ukraine. The phenomenon of crime in the field of banking, its current state, trends and patterns of development are studied. The factors of social conditionality of criminal-legal protection of the sphere of banking activity in Ukraine are determined, the state of protection of the sphere of banking activity of foreign countries at the criminal-legal level is investigated.

While supporting this statement, it is worth noting that investigating and determining that there is internet crime is laudable initiative adumbrated by the government of Ukraine in combatting electronic crimes, but there is still increase in the rate of violation of electronic payment making it questionable. One thing is in putting in place great and wonderful mechanisms in combatting these crimes, the other is at the level of proof or evidence that there has been violations of electronic payment. It becomes extremely difficult task in establishing that the crimes committed were as a result of electronic payment.

The problems of Ukrainian banks work innovation are investigated in the article Bondarenko and Politylo ("Banking innovations as effective functioning of the bank market need", 2018). The main attention is paid to the issue of the importance and necessity of banks innovative activity for providing their effective development in the market. Moreover, the foreign experience of innovative banking products and technologies has been worked out and major global banking innovations directions are highlighted.

The article Nikiforchuk's (2018a) "Features of the qualification of crimes committed in the field of bank electronic payments, that counteract them" is devoted to the analysis of crimes committed in the field of bank electronic payments and such an element of criminal law characteristics as a qualification of a crime of this category. The main factors considered the concept of countering crimes committed in the field of electronic banking payments.

Another scientific article ("Electronic Money in the Sphere of Financial and Banking Crimes: Problems and Definition") Nikiforchuk (2018b) analyzed the existing definitions of electronic money, which are used in the financial and 
banking sector and the development on their basis of their own position towards disclosing crimes committed in the field of electronic banking and payments. This is due to the fact that the world banking system actively uses new elements for settlements and payments. Given the worldwide trend in the financial and banking sector to use new types of payments and their implementation between banks in the form of electronic means of payment and electronic money as its means of payment, Ukraine has also connected to these innovations. Legislative acts introduced the terms «electronic money» and «electronic means of payment».

As Chaplian (2020) notes in his study: «Despite the large number of studies on the issuance and circulation of these objects, almost all of them study either cryptocurrencies or electronic money, without paying attention to a comprehensive approach to electronic means of payment. As a result, scientific sources do not provide a holistic view of electronic means of payment as a set of specific objects that exist in electronic form and, along with money, are used to make payments. In addition, scientists do not understand which objects belong to this set».

\section{Methodology}

Nowadays, any research should be based on the use of appropriate scientific methods that allows to achieve the purpose of the work, to make scientifically substantiated conclusions and to suggest appropriate ways to solve this problem. The methodological basis of the work is an interdisciplinary approach, which is based on the modern paradigm of general theoretical and special knowledge of legal science. An objective analysis of studying the problems of combating offenses of using electronic payment systems has become possible due to the use of a set of methods of general and special scientific knowledge.

With the help of the dialectical method of cognition, it was possible to clarify such concepts as "payment system", "electronic payment" and "combating cybercrime".

The method of documentary analysis and analytical method have been used in the scientific substantiation of theoretical conclusions. In particular, the authors have concluded that the solution of the existing problems in the field of combating offenses related to the use of electronic payment systems is possible only through comprehensive and multilateral research.
The information and analytical basis of the scientific research was the regulatory base regulating relations in the field of combating offenses in the field of using electronic payment systems, as well as scientific achievements and applied developments of scholars and practitioners of Ukraine and abroad. What a wonderful euphoria of establishing and accepting great policies, and methodology in proving or providing that truly they exists offences as a result of electronic payment contract. With all its beautiful mirror of establishing that offences are experienced in electronic payment is interesting, but proving it or establishing that one of the parties violated this area of the law becomes an oblivious nightmare and myth in the country.

Data collection was carried out through two techniques: document analysis and observations, followed by data reduction, data display, and conclusion. Mixed methods of data collection were utilized which enabled the researchers to collect both primary and secondary data. For a secondary source of data literature was consulted for the study.

All stated methods were used with regard to interdependence and interconnection.

\section{Results and Discussion}

The need for electronic payment systems has grown dramatically after the inception of online shopping and eCommerce websites. The Epayment system made it convenient for the customer to pay for anything at any time. The COVID-19 pandemic has increased the need for electronic payment systems as it has forced people to stay at home. However, businesses need to work on their electronic payment systems if they want to provide better service (Digipay, 2021).

That the operation of electronic means of payment is based on different technologies (blockchain or other), the issue is governed by different approaches (prepaid or non-prepaid means of payment), they have different legal nature (obligations or general status of an individual object civil rights, as in traditional cryptocurrencies). But at the same time, despite such obvious differences, by their civil law regime and the peculiarities of turnover and virtual currencies, and electronic money, and stablecoins are ideal disembodied things, and from the standpoint of the ratio of money, these objects have reason to be recognized monetary substitutes in their doctrinal definition (which, incidentally, should encourage the legislator to 


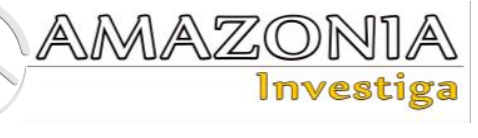

clarify the legislative definition of the concept of monetary surrogate and the possible introduction of the term "electronic monetary substitute"). These objects, the internal legal nature of which is leveled and replaced by the status of homogeneous units of account, perform exactly the same functions: act as a means of exchange and payment, and have every reason to use as a means of accumulation (Chaplian, 2020, p. 256).

The formation of the payment system as a component of the electronic payment system is carried out depending on the type of electronic money. The content of the work of payment systems based on smart cards is that users download payment instruments, in the process of their use, from bank accounts to smart cards or PC-files. While making a purchase with the help of such tools, first the availability of the required amount is checked, then this amount is deducted from the current balance of the buyer and is added to the deposited amount of the "supplier" (Trubin, 2013, p. 64).

The electronic money system is a model with a set of subsystems that allow electronic value to move under the control of the system administrator, who controls the security for the creation and circulation within the system (Ivasiv, 2011). Payment transactions are carried out through the banking network, using different payment systems that is quite convenient for customers. The high popularity of the banking network is evidenced by the data from the Bank for International Settlements (for example, the volume of electronic money transactions in 2005 amounted to $\$ 41$ million, in 2010 - $\$ 25$ billion, in 2015 - $\$ 400$ billion. This figure is annually growing (Riadinska et al., 2018, p. 88; Nikiforchuk, 2018b, p. 159).

As a result of the massive banking crisis, which Ukraine also faced after the beginning of the reform of the banking sector, the Government of the country was faced with the issue of creating effective mechanisms for detecting and neutralizing offenses in this area. In particular, one of the components of this reform was the audit, which proved that most banks and other financial institutions registered in Ukraine violate or have repeatedly violated the legislation in the banking sector, as well as financial regulation.

Due to the detection of mass violations and frauds by the state agencies of Ukraine, which took place in the activities of most banking institutions, a great part of the latter began to go into liquidation by relevant court decisions. The consequence of such a large-scale and almost simultaneous liquidation of banking and other financial institutions was a kind of "panic" in the financial and securities markets of Ukraine, and the Ukrainian national currency (hryvnia) began to depreciate against economically developed countries. However, due to the professional and timely activities of the leadership of the National Bank of Ukraine and the Cabinet of Ministers of that time, it was possible to stabilize the national currency, to introduce the supervision mechanism over the financial institutions and banks (National Bank of Ukraine, 2021).

The Government of the country has taken examples of successful settlement of interfinancial and interbank relations as a kind of pattern, which are implemented in developed countries of Western Europe and the United States of America. For example, one of such effective tools can be considered the specification of the subjects of crimes' corpus delicti committed with the use of electronic payment systems. Besides, in contrast to the legislation of Ukraine, there is criminal liability for fraud of using electronic means of payment or payment devices in some developed countries. This indicates that it is necessary to make qualitative amendments to the national legislation of the country in order to properly ensure the use of payment systems in Ukraine. Among other things, the newly created norms of laws and other regulatory acts should clearly and unambiguously prescribe mechanisms that should allow government agencies and independent regulatory agencies to audit the activities of banks and financial institutions (National Bank of Ukraine, 2021).

Specification of the list of permitted activities of banking and other financial institutions, creation of a public step-by-step procedure for the registration and verification of their daily activities is also important. We can say in the context of this issue that the most attractive and illustrative example of the successful experience of such a settlement of this area are the continental countries of Western and Central Europe. The list of such states should include Switzerland, Austria, Germany, France, etc., since those countries have a long tradition of codification, unification and systematization of legislative acts in various fields of law. In addition, those countries consistently have a fairly high level of reliability of banking institutions and the operation of payment systems of various kinds, including electronic ones. It is surely guaranteed by an extremely strong level of 
security of financial and other institutions and organizations.

It is clear that the crucial factor in counteracting the numerous cases of crimes and offenses that occur in the field of electronic payment systems is the introduction of criminal liability for persons who are the subjects of such crimes. In this context, we have the opportunity to assess the extremely successful experience of a number of developed countries in continental Europe, whose legal system is most similar to the Ukrainian one. In particular, those are such countries as the Republic of Poland, Switzerland, the Republic of Finland and other countries. According to their example we find that a clear and unambiguous criminal sanction for a specific crime is a significant factor in influencing potential offenders by convincing them that the potential "benefit" of such a crime will be less than the risk of punishment.

According to some authoritative studies conducted by experts in banking, finance and legal spheres, the introduction of such penalties, namely the creation of clear criminal liability for various types of abuse in the field of using electronic payment systems is a really effective way to positively solve this problem. However, researchers emphasize that this method of combating financial crimes will be most effective only if it is combined with the establishment of order and clarity in the functioning of institutions and agencies that are subjects of financial and banking activities. It is also necessary to ensure advanced progress in the field of high technologies and their timely implementation into daily activities in this area (National Bank of Ukraine, 2015).

Recently, several "dangerous actions" have been also criminalized and more clearly defined in national legislation of Ukraine. For example, the Law of Ukraine "On Amending Certain Legislative Acts of Ukraine on Liability of Persons Related to the Bank" dated from March 2, 2015 No. 218-VIII" (Law of Ukraine, 2015) supplemented the Criminal Code with the Articles 218-1 "Bringing the Bank to Insolvency" and 220-1 "Violation of the Procedure for Maintaining the Database of Depositors or Procedure for Reporting".

Another very important component of combating criminal offenses arising from the use of electronic payment systems is the development and support of the introduction of modern achievements in the field of high technologies. This thesis is supported by the fact that the introduction of advanced information technologies by financial institutions assists to the increase of productivity and the quality of their services. It should be noted that technologies allowing more efficient and secure operation of electronic payment systems, services and applications in the country have recently gained rapid spread in Ukraine. This fact was mainly due to the situation when Ukrainian electronic payments market was strongly influenced by tendencies of the developed world (USA, UK, Belgium, Germany, the Netherlands, etc.). The list of the latter includes China, Japan and South Korea as three leading countries in the field of high technologies development among Eastern countries. The only difference between those three economic giants is that, unlike the People's Republic of China, Japan and South Korea are legal and democratic countries with full transparency of state authorities' activities and a very strong level of privacy and protection of technologies. The fact that those two countries have a high culture of law, transparency and democracy has led to the development of high technology sphere (including electronic payments and systems) in full compliance with the principles of unconditional protection of intellectual property rights. Moreover, it is applied to the intellectual property rights of persons-developers of electronic payment systems, as well as the intellectual property rights of persons who are customers using these electronic payment systems.

Thus, in contrast to those democratic Asian states with real rule of law and a high rating of individual freedom and respect for private and intellectual property, the situation in China is different. Given that this country is under the authoritarian rule of the Communist Party, it is important that it does not respect the fundamental rights and freedoms of individuals as much as it is in legal countries. Therefore, the specifics of the development of electronic payment systems in this country is the frequent failure of developers to respect human rights and freedoms (for example, the right to privacy, the confidentiality of correspondence, the right to private property, etc.). Besides, the state authorities of this country have been repeatedly noticed in the theft of technologies and plans for potential developments of other states, mostly Western. Thus, an example of the development of Chinese electronic systems is not desirable for Ukraine. After all, Ukraine, being a European country, tends to share cultural values, to ensure rights and freedoms. 


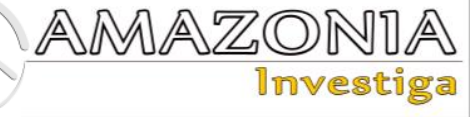

To conclude the review of the peculiarities of the functioning of electronic payment systems in developed Asian countries, we can point out that there are several other countries in this region, which, although not on such a large scale, but demonstrate advanced elements of electronic payment systems. We can confidently add Singapore to such countries, which, despite the existence of a ruling authoritarian regime, provides real protection and inviolability of intellectual property rights. All subjects of public relations are also protected by the laws of the state from unlawful encroachment on their private property and other property interests.

Another country that is able to effectively ensure and maintain the functioning of modern electronic payment systems at a high global level is Taiwan. There is an effectively functioning legal system in this country, which, incidentally, remains unrecognized by some other countries and has significant contradictions with mainland China. Such legal system promotes comfortable and unhindered business on the territory of Taiwan. Therefore, Taiwan is known for the fact that, despite its small size, it has "forced" the surrounding states to recognize it as equal subject through the creation and development of its own economic power. Of course, this economic greatness would not be fully significant if it were not based on Taiwan's high-tech leadership, in particular in the financial and banking sectors.

Undoubtedly, Ukraine should follow the example of advanced Western countries, such as the United States, Canada and EU member states. The United States is unequivocally considered a world leader in the protection of payment systems, protection and enforcement of banking and financial institutions. A high level of electronic payment protection standards is a hallmark of the American system.

Taking into account this fact, representatives of the Ukrainian authorities who came to power after the Revolution of Dignity were able to establish some productive contacts with the structural departments of the US State Department, which made it possible to implement joint assistance programs for Ukraine. We can single out the National Program for Promoting the Security of Electronic Payments and Card Payments among such programs, the essence of which is to increase the efficiency of both individual elements of the financial and banking system of Ukraine and its competitiveness in general. This project was mostly created with the financial support of agencies and institutions run by the US government, and its coordination is carried out by the Ukrainian Interbank Association of EMA Payment System Members. Having been started in 2016, this project has already achieved some pre-planned results. In particular, the operational interaction between financial institutions (including banks) with units of the National Police (especially cyberpolice units), as well as other law enforcement agencies was increased during the processes related to the investigation of any offense in the financial and banking sector (Bondarenko \& Politylo, 2018).

It is worth noting that crimes related to the illegal use of electronic payments are among those most often encountered by law enforcement officers in their daily work. Due to such processes, there is the progress in the investigation of the specified crimes.

According to the results of the research, crimes related to the use of bank settlements and payments in most cases are committed by individuals, in some cases - by organized criminal groups, and have a high level of latency and, according to practice, are most often detected as a result of operative and. search activities. The complexity of this crime, in contrast to other criminal encroachments, is that crimes in the field of bank electronic payments are one of the new types of criminal offenses, since the terms of "electronic money" and "electronic means of payment" were introduced into the Criminal Code of Ukraine only in 2012 (Nikiforchuk, 2018a, p. 279). In addition, the complexity of counteraction to offenses committed with the use of electronic payment systems is manifested in the ramifications of the ways of committing such offenses. In particular, those are crimes related to:

1) encroachments on property;

2) management;

3) official activities and professional activities related to the provision of public services;

4) the use of electronic technologies, etc.

That is, one of the features of crimes committed with the use of electronic payment systems is that they are qualified not only under a special Article of the Criminal Code of Ukraine, but also under other related Articles of the Criminal Code of Ukraine, since such crimes are committed with the use of information and telecommunication technologies and tools. 


\section{Conclusions}

When preparing conclusions and recommendations based on the results of the study, the method of generalization was used.

Thus, summarizing the research, we can state that counteraction to offenses committed with the use of electronic payment systems is extremely urgent. This statement is based on the fact that more and more money is transferred and distributed through electronic means of payment. Such processes are greatly facilitated by the latest advances in high technology area, such as the blockchain system.

The distance and depersonalization of the owner of e-money increasingly makes it a powerful tool and a means of committing crimes. The complexity of the trace examination for electronic trace tracking, as well as the extreme remoteness from the place of commission or preparation of crime in case of the use of emoney makes it a powerful and extremely dangerous means of committing a crime. Therefore, in order to find out the criminal nature of the use of e-money and payments as means of committing crimes, it is necessary to study: a) the nature, meaning and legal regime of e-money and electronic payments; b) the mechanism of using e-money as a means of committing criminal offenses; c) legal features of regulating the circulation of e-money and the relations built around these payment instruments as separate subjects of relations (Vozniuk et al., 2020, p. 150).

Huge amounts of money currently appear in the so-called "black markets" or, to put it more modernly, in the "darknet". Therefore, a rather significant part of the current electronic payment systems derive from the activities of unregulated national legislation or underground market relationships. That is why it is important to combat offenses committed with the use of electronic payment systems. Counteraction to such crimes can be defined as a comprehensive system of measures aimed at preventing, detecting and investigating crimes in the field of using electronic payment systems, as well as preventing the occurrence of a criminal nature and preventing the recidivism of these crimes in the future. In this case, the main condition for the application of the specified measures is the legitimacy of their implementation, i.e. they must be carried out only by authorized entities of such activities. Subjects of counteraction in the field of using electronic payment systems must be authorized persons, the list of which is provided by the Criminal Procedural Code of Ukraine and the Law of Ukraine "On Operative and Search Activity".

\section{Bibliographic references}

Bondarenko, L., \& Politylo, M. (2018). Banking innovations as effective functioning of the bank market need. Investytsiyi: This practice dosvid, $\quad 3, \quad 5-8$. https://ur.snau.edu.ua/?p=2640https://www.r esearchgate.net/publication/346952893_BA

NKING_INNOVATIONS_AS_EFFECTIV E_FUNCTIONING_OF_THE_BANK_MA RKET_NEED

Chaplian, S. (2020). Common and distinctive signs of electronic means of payment. Knowledge, Education, Law, Management, vol. 2, 3(31), 250-258. Retrieved from http://kelmczasopisma.com/ua/viewpdf/1293

Digipay. (January 4, 2021). What do you need to know about Electronic Payment Systems? Retrieved from https://www.digipay.guru/blog/electronicpayment-systems/

Herasymov, V. O. (2018). Structural analysis of crimes within the banking sector. Law and Safety, 66(3), 57-62. Retrieved from http://pb.univd.edu.ua/index.php/PB/article/ view/65

Ivasiv, B. (2011). Electronic Money: Opportunities, Tendencies for Development and Consequences of the Dissemination. Financial Market of Ukraine, 5, 8-9.

Klochko, A. M. (2019). Theoretical and Applied Principles of Counteracting Crimes in the Banking Business Sector in Ukraine: monograph. Sumy: FOP Shcherbina IV, 476 p. https://ur.snau.edu.ua/?p=2640

Klochko, A. M. (2020). Theoretical and practical grounds of counteracting crime in the field of banking in Ukraine (Master's thesis for the academic degree of the Doctor of Law). Sumy National Agrarian University of Ministry of Education and Science of Ukraine Institute of State and Law, V. M. Koretsky of the National Academy of Sciences of Ukraine, Kyiv. http://idpnan.org.ua/files/2020/klochko-a.m.teoretiko-prikladni-zasadi-protidiyizlochinam-u-sferi-bankivskoyi-diyalnosti-vkrayini_d_.pdf

Law of Ukraine No. 2346-III. Bulletin of the Verkhovna Rada of Ukraine. 2001. No. 29. Art. 137.

Law of Ukraine No. 218-VIII. Verkhovna Rada of Ukraine, March 2, 2015. Retrieved from https://zakon.rada.gov.ua/laws/show/2189\#n17. 


\section{AMAZOND㲏 \\ 1กveรtปำ}

National Bank of Ukraine (2015). Banking System of 2015: Challenges and Perspectives. Kyiv. Retrieved from https://old.bank.gov.ua/doccatalog/document ?id=14741673

National Bank of Ukraine (2021). General Indicators for the Development of Electronic Cards Market in Ukraine. Retrieved from https://bank.gov.ua/en/

Nikiforchuk, V. (2018b). Electronic Money in the Sphere of Financial and Banking Crimes: Problems and Definition. Scientific Herald of National Academy of Internal Affairs, 2(107), 158-171.

Nikiforchuk, V. D. (2018a). Features of the qualification of crimes committed in the field of bank electronic payments, that counteract them. International law herald: actual problems of the present (theory and practice), 3-4(12-13), 278-285. Retrieved from http://ojs.nusta.edu.ua/index.php/ojs4/article/ download/251/339/.

Riadinska, V., Dei, M., \& Rudenko, O. (2018). European standards of the circulation of electronic money and the prospects of its implementation into the law of Ukraine. Association agreement: from partnership to cooperation (collective monograph). Hamilton, Ontario: Accent Graphics Communications \& Publishing.

Streltsov, L. (2017). The System of Cybersecurity in Ukraine: Principles, Actors, Challenges, Accomplishments. Eur J Secur Res, 2, 147-184. doi: https://doi.org/10.1007/s41125-017-0020-x

Trubin, I. O. (2013). Legal Principles of Electronic Money Functioning in the Sphere of Electronic Commerce: monograph. K.: Alerta.

Vozniuk, A. A., Savchenko, A. V., Tarasevych, T. Y., Dudorov, O. O., \& Klymenko, O. A. (2020). Electronic Money and Payments as Means of Committing Crimes. Academic Journal of Interdisciplinary Studies, 9(4), 150. DOI: https://doi.org/10.36941/ajis-2020-0069. 